\title{
Quality control of commercial samples of "arnica" (Arnica montana and Solidago chilensis) from Rio de Janeiro, Brazil
}

Pedro Nogueira Araújo ${ }^{1}$

André Luis Alcantara Guimarães²

Mirian Ribeiro Leite Moura ${ }^{3}$

Ana Cláudia de Macêdo Vieira ${ }^{4}$

\section{Abstract}

Arnica montana is a medicinal plant native to Europe and used topically to treat contusions, inflammations, and muscular aches. Studies have confirmed the anti-inflammatory activity of extracts of this plant, which can be attributed to the presence of lactones. Its use in Brazil has traditionally been substituted by the species Solidago chilensis, which demonstrates similar therapeutic activity but is more adapted to a tropical climate. It is known that $S$. chilensis can be used as a substitute for $A$. montana as they both contain similar active compounds. We acquired eight different commercial brands of "arnica" sold in Rio de Janeiro State, Brazil, in 2013. The analyses of these products were divided into four categories: labeling, macroscopic, microscopic, and microchemical analysis. Labeling analysis followed RDCs ("Resolução de Diretoria Colegiada") standards (10/2010 through 26/2014). The morphological analyses were performed using microscopic techniques and were followed by microchemical analyses. Our results indicated that none of the samples were in complete conformity with labeling standards, the material was poorly conserved, contaminants were abundantly present, the species were incorrectly identified, and the directions of use were inadequate and potentially dangerous to human health.

Keywords: Plant anatomy. Chemical markers. Medicinal plants. Traditional phytotherapeutic products. Quality markers.

\section{Introduction}

Arnica montana Linné is a medicinal plant native to Europe that demonstrates antiinflammatory and antimicrobial activity and is used topically for treating contusions, inflammations, and muscular pain due to the presence of sesquiterpene lactones of the helenalin type (LORENZI; MATOS, 2008; HALL, 1979; LYSS et al., 1997; BARNES; ANDERSON; PHILLIPSON, 2012). Its use in Brazil has been traditionally substituted by the species Solidago chilensis Meyen, also known as Solidago microglossa DC, which is more adapted to a tropical climate and demonstrates similar anti-inflammatory activity due to the presence of similar chemical constituents (LORENZI; MATOS, 2008; THE PLANT LIST, 2016; GASTALDI et al., 2018; ATHAYDE et al., 2019, KELLY; OLIVEIRA; VALVERDE, 2020).

1 Universidade Federal do Rio de Janeiro - Laboratório de Farmacobotânica, Faculdade de Farmácia. araujopn@gmail.com

2 Universidade Federal do Rio de Janeiro - Laboratório de Farmacobotânica, Faculdade de Farmácia. andreguimaraes@pharma.ufrj.br

3 Universidade Federal do Rio de Janeiro - Laboratório de Controle Bromatológico e Microscópico, Faculdade de Farmácia. mirian.rlm@gmail.com

4 Universidade Federal do Rio de Janeiro - Laboratório de Farmacobotânica, Faculdade de Farmácia. anavieira@gmail.com. Av. Carlos Chagas Filho, 373, CCS, Bloco A, $2^{\circ}$ andar, sala 22, Cidade Universitária, Rio de Janeiro, Brasil, CEP: 21.941-902. 
A. montana is mostly used in the form of a hydro-alcoholic infusion of its inflorescences that is applied topically (BRAZIL, 2010). The traditional medicinal use of Solidago chilensis consists of the same type of infusion, although using its leaves and aerial portions (LORENZI; MATOS, 2008). Woerdenbag et al. (1994) described the hepatotoxicity of $A$. montana, attributable to the cytotoxic action of lactones sesquiterpenes, thus not recommending its oral ingestion. The FDA classifies the species as a "dangerous plant", forbidding its use in formulations to be ingested (NEWALL; ANDERSON; PHILIPSON, 2002). There are, however, no clinical studies condemning the use of Solidago chilensis by oral ingestion - nor studies that demonstrate the safety of that form of use.

The sale of traditional phytotherapeutic products in Rio de Janeiro State (and all of Brazil) was regulated by "Diretoria Colegiada" (collegiate directorate) resolution (RDC) n 10 of 2010 of the National Health Surveillance Agency ("Agência Nacional de Vigilância Sanitária" - ANVISA), which was revoked in 2014 by RDC $n^{\circ} 26$ and replaced with new provisions concerning labeling, technical terms, and notifications (BRAZIL, 2014a). For any herbal medicine to be marketed as a traditional phytotherapeutic product, it must be exempt from the necessity of a medical prescription and demonstrate effectiveness based on its traditional use and pertinent bibliography. Nonetheless, there are plants whose commercialization is not permitted, as listed in Annex 1 of $\operatorname{RDC} n^{\circ} 26$. Traditional phytotherapeutic products can also be exempt from registration if listed by the Normative Instructions (IN) $\mathrm{n}^{\circ} 02$ and 13 of May/2014 (Brazil, 2014a; 2014b). Arnica montana is the only species currently encountered on that list.

As such, the present work examined different brands of "arnica" commercialized in Rio de Janeiro State using macroscopic, microscopic, and microchemical analyses as well as evaluations on labeling quality and the plant material itself. These studies were performed under the current regulations and the specialized literature concerning the species Arnica montana and Solidago chilensis.

\section{Materials and methods}

\section{Obtaining samples}

We examined eight samples of "arnica" from different brands acquired from randomly chosen commercial establishments in Rio de Janeiro State in 2013. When the samples were acquired in 2013, RDC 10/2010 norms still ruled, so that our analyses are based on those as well as on the more recent requirements of $\mathrm{RDC} \mathrm{n}^{\circ} 26 / 2014$, when applicable.

\section{Labeling analyses}

The labeling information on the products was evaluated under the discipline of RDC no 10 de 2010 (BRAZIL, 2010), which regulates the notification of plant medicines to the National Agency of Public Health (Agência Nacional de Vigilância Sanitária - ANVISA). The commercial registries (CNPJ) of the eight samples were verified by consulting the Internet pages of the regulatory organs ANVISA and MAPA. The descriptive statistical analyses regarding labeling data were performed using Microsoft Excel $2013^{\circledR}$.

\section{Macroscopic and microscopic analyses}

The packaged materials were opened over plastic trays and photographed using a Canon Rebel T1i digital camera (15 megapixels). The most abundant contaminant elements were separated and identified as extraneous plant species or as plant parts different from those cited on the labels. These 
analyses were made using an Olympus ${ }^{\circledR} \mathrm{CH} 30$ optical microscope. The morphologies of the plant parts were compared with Solidago chilensis samples collected in Campo Grande, in the municipality of Rio de Janeiro, RJ, and with examples in the literature (BRAZIL, 2019; PANIZZA; GROTTA, 1965; LORENZI; MATOS, 2008). Ten stem and leaf fragments were selected from each sample and rehydrated in a $50 \%$ solution of glycerin in ethanol absolute (P.A.).

The rehydrated material was analyzed based on the methodology described by Kraus and Arduin (1997). Sections for microscopic examination were cut using a tabletop microtome at thicknesses varying from $10 \mu \mathrm{m}$ to $25 \mu \mathrm{m}$ (depending on the quality of the sample). The slides were viewed using an Olympus ${ }^{\circledR} \mathrm{CH} 30$ optical microscope and documented using a Moticam $2300^{\circledR}$ camera coupled to it, focusing on the region of the central nerve, the lateral nerves of the leaves, stems, and any contaminant material encountered. The images were processed using Motic Images Plus 2,0 ML ${ }^{\circledR}$ software. The same procedures were used for the Solidago chilensis standards conserved in $70 \%$ ethanol. The results were compared with the Solidago chilensis standards regarding the presence of unique anatomical characteristics of the species (PANIZZA; GROTTA, 1965). The samples were also inspected for the characteristics of Arnica montana as described in the "Farmacopéia Brasileira" (BRAZIL, 2019).

\section{Chemical analyses}

For chemical evaluation, plant material from each brand was randomly selected. Then, $15 \mathrm{~g}$ of dried material of each sample was macerated in $100 \mathrm{~mL}$ of absolute ethanol for five days at $25{ }^{\circ} \mathrm{C}$. The sample filtrate was dried with a rotary evaporator $\left(60{ }^{\circ} \mathrm{C} ; 100 \mathrm{rpm}\right)$. The chemical analyses were performed using chemical tests for the identification of flavonoids, following the methodology proposed by Matos (1997). We added $3 \mathrm{~mL}$ of each extract into three numbered test tubes, following $\mathrm{pH}$ changes with hydrochloric acid $(\mathrm{HCl} 5 \%)$ or sodium hydroxide $(\mathrm{NaOH} 3 \%)$ (3.0, 8.5, and 11.0, respectively). The evaluation of each type of flavonoid was based on the color changes according to the $\mathrm{pH}$ range. For positive control, extracts of Achyrocline satureioides (flavonoids) were also used.

\section{Results and discussion}

The federal government of Brazil has been promoting research and development of medicinal plants and phytotherapeutics since 2006, beginning with Ministerial Decree MS/GM $n^{\circ}$ 971, of May 3, 2006, which approved the National Policies of Integrative and Complementary Practices (PNPIC) within the Unified Health System (SUS). In the case of "arnica", the Brazilian species Solidago chilensis was included in the National List of Medicinal Plants of Interest to SUS (RENISUS) (BRAZIL, 2009), under the synonym Solidago microglossa DC. Plants on the list are the subject of studies supporting the use of traditional medicinal herbs, to ensure the safety of the country's citizens within the directives of the National Program of Medicinal and Phytotherapeutic Plants (BRAZIL, 2008). S. chilensis was not, however, listed in Annex I of the RDC 10/2010, and therefore could not be sold as a medicinal plant in 2013. In opposition to the species A. montana, the S. chilensis was not listed again in IN $\mathrm{n}^{\circ} 2$ of 2014, as it lacked any registry whatsoever for commercialization, including clinical tests (which only Arnica montana has fulfilled until the current moment). As mentioned above, there are incentives for research on Solidago chilensis and its traditional use, although adequate studies that could allow its commercialization have not yet been undertaken. 


\section{Labeling analyses}

The labeling analyses of samples I to VIII, in compliance with RDC no 26/2014 norm, are summarized below (FIGURE 1).

Figure 1 - Labeling analyses of the 8 samples obtained in commercial establishments in Rio de Janeiro State (RJ) in 2013.

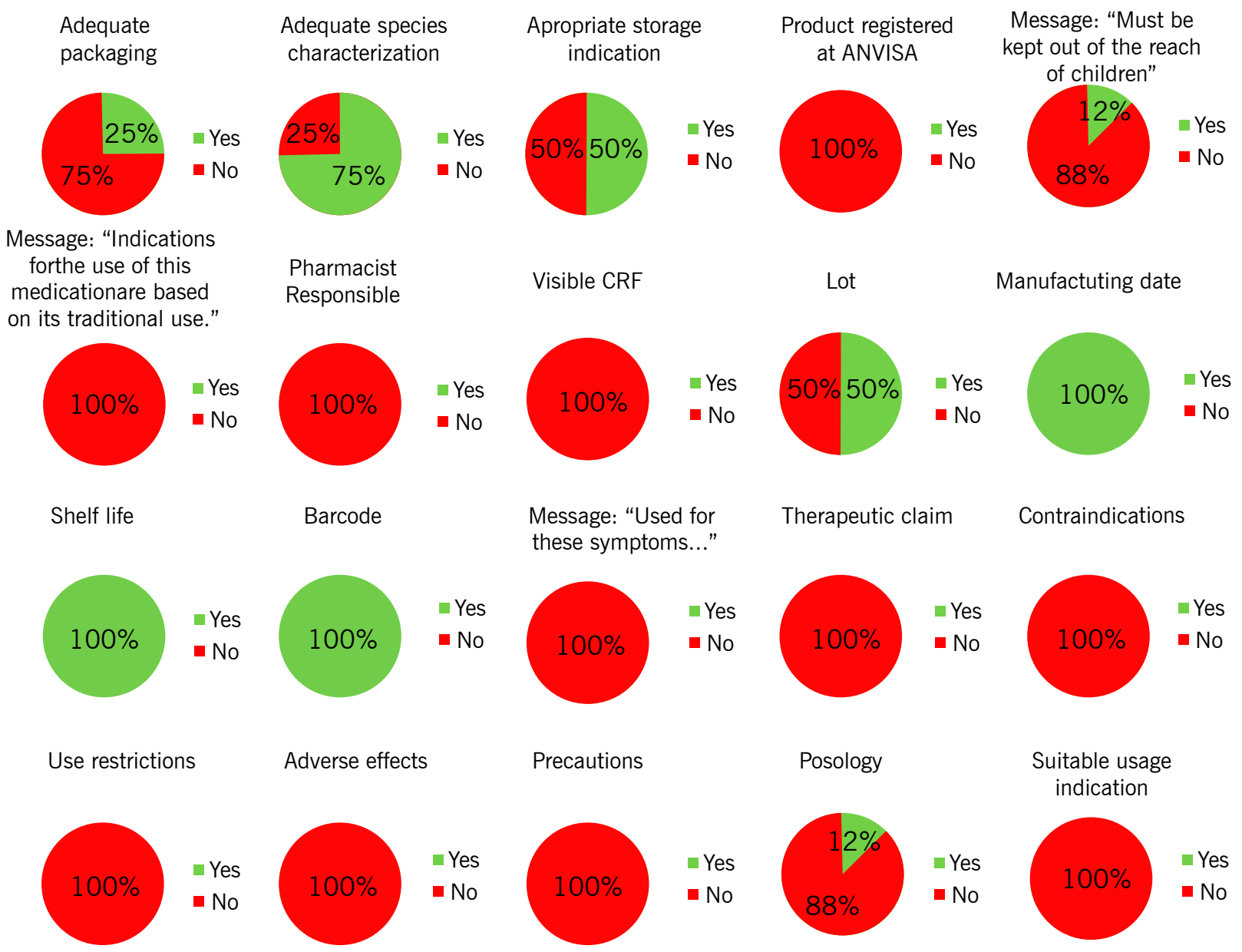

Source: Elaborated by the authors (2020).

It was verified that none of the samples were in full accordance with RDC $n^{\circ} 26 / 2014$ terms. Amongst the violations encountered, there were the following:

1) The absence of information regarding storage (such as "store in a cool dry place" or "store at room temperature");

2) The lack of warnings concerning child safety ("keep out of reach of children");

3) No advisory message stating that it is not a drug, deriving rather from other origins ("indications for the use of this medication are based on its traditional use");

4) No indications of a responsible pharmacist; samples III and IV indicated only the chemist responsible (which is not a regulation requirement);

5) Inadequate directions of use, namely the ingestion in the form of tea (oral infusion). The labels of samples II to VIII all show pictures that resemble a teacup; 
6) Samples I, II, III, V, VII, and VIII were sold in translucent packaging (not opaque), which allowed sunlight contact;

7) None of the samples contained observations concerning the use by pregnant women ("Pregnant women should not use this product without consulting a qualified health professional");

8) The plant species were not identified on samples IV and V, which made the analyses more difficult, since there were no established standards for comparison.

9) Samples II and III indicated their contents as Arnica montana but no floral capitula could be found, which identifies with the cited species. Being the package transparent, it was possible to observe the presence (or not) of the floral capitula.

Initial inspections were carried out to determine if the packaging material was adequate and if the samples were being sold within their shelf-life limits (if that information was available), to prevent quality loss during storage. Our analyses of the packages labeling demonstrated several quality infringements according to RDC 10/2010 standards (BRAZIL, 2010) - standards that range from "no immediate risk to consumer health nor to the integrity of the material" (Points 1 to 3), to "immediate risk to consumers based on factors that impact guarantees of quality and integrity of the plant remedy" (Points 4 and beyond). As of the ruling legislation, the indication of a pharmaceutical technician is no longer required on the packaging of traditional phytotherapeutic products - which is counterproductive, as these new regulations were imposed to increase vigilance over plant remedies being sold in that country.

We were not able to find any previous studies examining the labeling of arnica samples for traditional use, either as Solidago chilensis or Arnica montana, making the present work the first effort to examine this facet of "arnica" marketing. In that sense, the commercialization of plant drugs in Rio de Janeiro State needs to be better regulated and enforced, as the falsification of natural products is considered a crime (article 275, chapter III of the Penal Code), with penalties ranging from 1 to 5 years in prison and/or fines (BRAZIL, 1998).

In general, the investigated samples were in an extremely poor state of conservation, which affected the quality of the sections prepared for microscopic examination and made the analyses and recognition of their essential structures harder. Nonetheless, the similarities and discrepancies observed in terms of the standards allowed the identification of the materials and diagnoses of their quality, which, associated with the chemical analyses, were sufficient for our objectives.

Current legal requirements stipulate that quality control of raw materials for traditional phytotherapeutic products, especially plant remedies, must include macroscopic and microscopic identifications of the matter commercialized as well as chromatographic profiles of their extracts (BRAZIL, 2014a; BRAZIL, 2019). Nevertheless, chemical tests with specific reagents for each assessed metabolite class associated with morphological analyses could also be useful regarding quality control of plant drugs. Also, the use of other tests rather than those from pharmacopeias is allowed since the authors provide a detailed description of such methodologies (BRASIL, 2014a).

RDCs $10 / 2010$ and $26 / 2014$ specify that the weight of the plant constituent must be displayed on the primary or secondary packaging of any traditional phytotherapeutic product (although these provisions do not specify permitted weight variations). This feature was, however, regulated by INMETRO decree $n^{\circ} 248 / 2008$, which focuses on the verification of the weights and volumes of commercial products (BRAZIL, 2008). Studies are pointing out variations in weights of plant material in the fourth and fifth editions of "Farmacopeia Brasileira", although they have generally focused on medicines. In the present case of arnica, samples I, IV, V, VII demonstrated average variations of $28.01 \%$ of real product weights 
below those declared on the packaging (featured on red font) - demonstrating variations greater than one-quarter of the declared weight. Samples I, II, III, V, and VII had primarily plastic wrappings, totally exposing the products to ambient light sources, while the labels themselves were made of paper - contrary to provisions designated to assure packages would protect the plant remedies from solar radiation and possible alteration and/or degradation of their contents. These results demonstrate serious issues with the packaging from a qualitative point of view. There are no properly established parameters on tolerated variations of product weights - demonstrating a lack of official concern regarding quality and uniformity aspects of those products. The ANVISA regulations (RDC 10/10 and RDC 26/14) are incomplete on what concerns the weight of the phytotherapeutic products in the market.

\section{Anatomical analyses of the samples}

\section{Sample I}

The manufacturer identified the species as S. microglossa - morphological and anatomical patterns were described for comparison (FIGURE 2A-C) with each sample and A. montana (FIGURE 2D). The heterogeneity of the sample was duly noted, with stems of different thicknesses, leaves of various tones, being both quite fragmented (FIGURE 2E). We also observed glandular trichomes on the abaxial epidermis in the midrib and lateral bundles next to the main vascular bundle. There were no secretory canals associated with the vascular bundles (FIGURE 2F). The leaf outline is biconvex and palisade parenchyma was observed on the adaxial face, with spongy parenchyma immediately below (FIGURE 2F). The stem demonstrated vascular bundles arranged in a ring, with no aerenchyma in the cortex. A fibrous pericycle was little evident. This sample could not be classified as Solidago chilensis due to the absence of markers of that species (FIGURE 2G). The stem contaminants demonstrated a well-developed secondary vascular system, with no fibrous pericycle, secretory canals, or aerenchyma. The cortical parenchyma was thin and without evident intercellular gaps. The medulla demonstrated some degenerated regions, indicating the poor conservation of the sample (FIGURE $2 \mathrm{H}$ ).

\section{Sample II}

This sample, labeled as $A$. montana, exhibited a complete absence of floral capitula and was contaminated by grasses. It was composed of leaves and stems that were extremely thinly divided, totally incongruent with the species declared on the label (FIGURE 2I).

Microscopic analyses revealed leaf blades with dorsiventral symmetry. Secondary vascular units were observed next to the principal units in the region of the central nerve, without associated secretory canals. Collenchyma was present only on the adaxial face, and the shape of the midrib was quite different from that of Solidago chilensis (FIGURE 2J). The stems did not show cortical aerenchyma. No secretory canals were observed in associations with the vascular bundles, and the medulla showed elongated cells, different from Solidago (FIGURE 2K). The contaminant leaves showed nerves parallel to the leaf blade with visible bulliform cells, as well as anatomical patterns consistent with monocots of the grass family (FIGURE $2 \mathrm{~L}$ ).

\section{Sample III}

We noted the presence of thick stems with soft medullar regions and the predominance of very finely divided leaves. Even though the label declared the species to be Arnica montana, the sample did not show vestiges of floral capitula (FIGURE 2M). The leaf fragments demonstrated characteristics 
resembling those of Solidago chilensis, with secretory canals associated with the vascular units, isobilateral palisade parenchyma in the leaf blade, and trichomes near the midrib (FIGURE 2N).

According to Panizza and Grota (1965), trichomes may or may not be present in S. chilensis. Of the stems recovered, only one was able to be studied. That sample showed collapsed cortical aerenchyma in some regions and vascular bundle placement like that associated with Solidago chilensis (FIGURE 20). Leaf contaminants were small in comparison to other leaves in the same sample, with secretory canals associated with the vascular bundles, indicating those might have been very young leaves of $S$. chilensis (FIGURE 2P).

Figure 2 - (A) Macroscopic aspects of Solidago chilensis. (B) Transverse section of the midrib region of Solidago chilensis. (C) Transverse section of the stem of Solidago chilensis. (D) Arnica montana as a medicinal plant. (E) General aspect of Sample I. (F) Midrib region, having glandular trichomes and vascular bundles without associated secretory canals. (G) Transverse section of the stem. (H) Transverse section of a contaminant stem. (I) General aspect of Sample II. (J) Midrib region. Collenchyma near the adaxial region, demonstrating palisade parenchyma and the remains of the mesophyll filled by spongy parenchyma. Medulla with elongated cells, common to Solidago chilensis. (K) Stem region. (L) Contaminant leaf, possibly Poaceae. (M) General aspect of Sample III. (N) Midrib region, with secretory canals associated with the vascular bundles. Isobilateral palisade parenchyma is separated by two layers of spongy parenchyma. Annular placement of the vascular bundles similar to the pattern of Solidago. (0) Transverse section of the stem. (P) Contaminant leaf. Bars: $(A)=1 \mathrm{~cm}$; $(\mathrm{B}, \mathrm{F}, \mathrm{J}, \mathrm{L}, \mathrm{N}, \mathrm{P})=200 \mu \mathrm{m}$; (C, G, H, K, O) = $100 \mu \mathrm{m}$. Rio de Janeiro State (RJ), 2013.

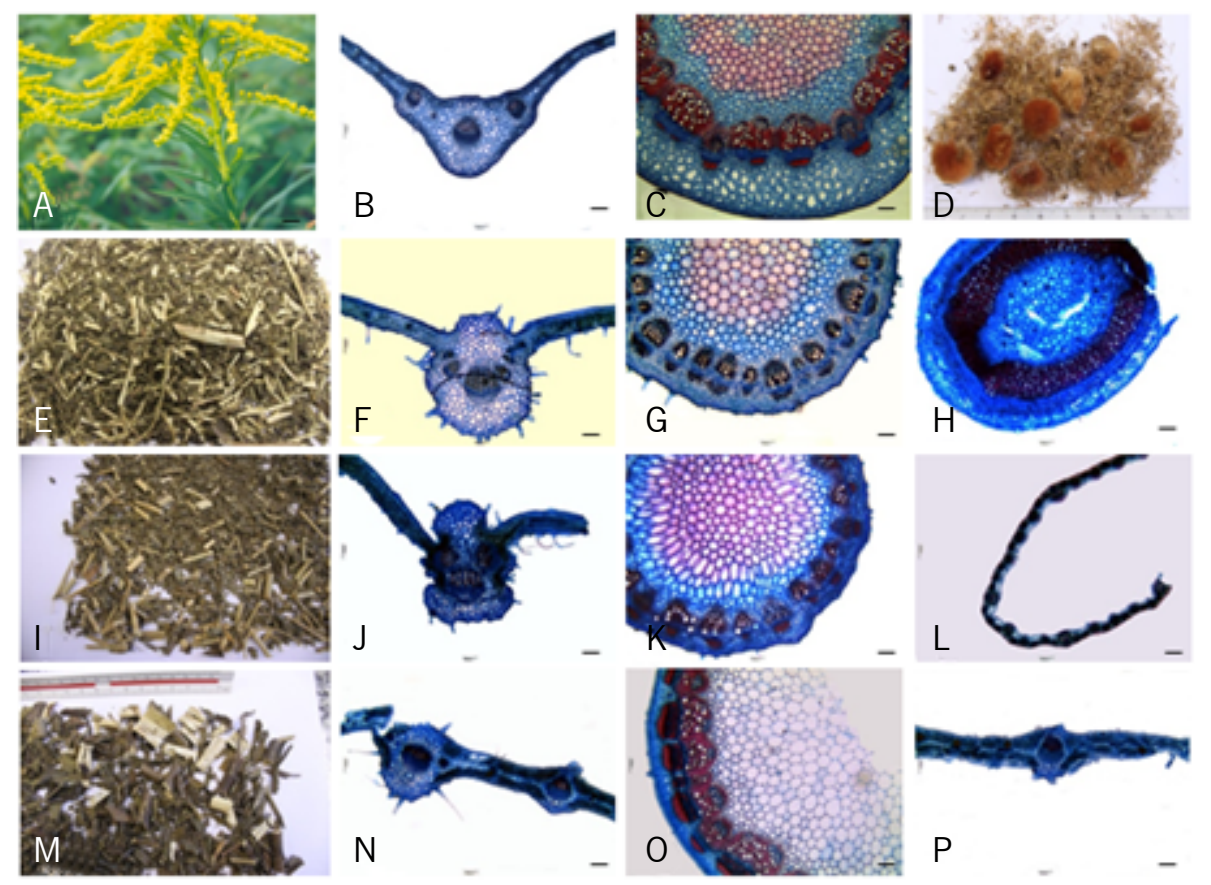

Source: Elaborated by the authors (2020).

\section{Sample IV}

The label did not specify the species, despite the use of the popular name "ARNICA". The sample contained stem fragments that were reduced to tiny particles, and leaves reduced to dust. The material was quite pale and there were portions of plant reproductive structures. There was an intense aroma of menthol. There were also stem shreds with distinct colors and fibrous aspects (FIGURE 3A).

The leaf fragments were extremely small, almost pulverized. There were several multicellular trichomes (FIGURE 3B). The stem showed a vascular system in transition to secondary growth; akin to the standard, but we could not observe any aerenchyma in the cortex. There were no secretory 
canals associated with the vascular bundles (FIGURE 3C). The stem contaminants did not show any secretory canals associated with the vascular bundles or aerenchyma (FIGURE 3D).

\section{Sample V}

The packaging was labeled "MONTANA LINNE" (sic), but no floral capitula of $A$. montana were encountered in the sample material. The plant matter was pulverized, with large amounts of shredded stems (FIGURE 3E). The leaves were morphologically analogous to those seen in Sample II. Vascular bundles were observed in the central region of the leaves, but without any associated secretory canals (FIGURE 3F). Likewise, the stems did not show secretory canals associated with the vascular bundles, and there was no evidence of aerenchyma, being therefore distant from the S. chilensis standard (FIGURE 3G). The stem contaminants showed signs of a periderm (FIGURE 3H).

\section{Sample VI}

This sample was labeled as Solidago chilensis. The material was well conserved, although $40 \%$ of the stem structures were in varying stages of development. More than one type of leaf was mixed within the sample. We encountered contaminant structures that appeared to be rhizomes, different from the pattern expected for Solidago chilensis (FIGURE 3I).

The leaves showed secretory canals associated with the vascular bundles, but the isobilateral palisade parenchyma was difficult to identify (FIGURE 3J). The vascular bundles contained phloem, with areas of lignified cells and associated secretory canals (FIGURE 3K). The leaf contaminants showed trichomes on the adaxial surface and anatomical traits different from the standard (FIGURE 3L).

\section{Sample VII}

This sample was labeled as S. chilensis. The material was predominantly composed of stems at different stages of development. There were floral structures comparable to those of the floral capitula of Asteraceae. The sample was very heterogeneous, with highly fragmented leaves, many of which were reduced almost to dust. We noted the presence of numerous leaf and floral fragments, possibly derived from grasses (FIGURE 3M).

The leaf fragments showed palisade parenchyma towards the abaxial surface in the midrib region, as seen in the Solidago chilensis standard (FIGURE 3N). The stems had many obliterated and degenerated regions in the cortex and pith due to the poor conservation of the material, although secretory canals associated with the vascular bundles could be identified (FIGURE 30). The contaminant leaf material of this sample showed anatomical similarities to Poaceae (FIGURE 3P).

\section{Sample VIII}

This sample was composed of leaves and stems, with the clear presence of grass contaminants. The stems demonstrated different covering tissues, characterizing different stages of plant development and/or contamination by various species (FIGURE 3Q).

Isobilateral symmetry was observed, and trichomes were identified in the midrib region, as well as secretory canals associated with the central vascular system. There were accessory vascular bundles with biconvex shapes, different from the standard sample, although there is the possibility, considering other characteristics, that the plant material in question did belong to the genus Solidago (FIGURE 3R). The stem showed visible aerenchyma and secretory canals associated with the vascular 
bundles (FIGURE 3S). The contaminant leaves encountered had anatomical features resembling those seen in grasses (Poaceae), as in samples II and VII (FIGURE 3T).

Figure 3 - (A) General aspect of Sample IV. (B) Midrib region. (C) Transverse section of the stem, showing the annular placement of the vascular bundles, similar to the pattern known for Solidago. Abundant multicellular trichomes. Aerenchyma not observed (D) Transverse section of a contaminant stem. (E) General aspect of Sample V. (F) Midrib region. (G) Stem region with annular vascular bundles, without associated secretory canals. Aerenchyma was not observed. (H) Detail of a contaminant stem. (I) General aspect of Sample VI. (J) Midrib region, showing a secretory canal associated with the vascular bundle. Isobilateral palisade parenchyma. (K) Transverse section of the stem. Note abundant extraxylary fibers adjacent to the phloem. (L) Transverse section of the midrib of a contaminant leaf. (M) General aspect of Sample VII. (N) Transverse section of the midrib, with isobilateral palisade parenchyma extending into its abaxial region. (0) Transversal section of a stem. (P) Transverse section of a contaminant leaf (Poaceae). (Q) General aspect of Sample VIII. (R) Transverse section of the midrib region of a contaminant leaf. (S) Transverse section of a stem, showing secretory canals associated with the vascular bundle, and well-defined aerenchyma $(T)$ Transverse section of a contaminant leaf. Bars: $(A)=1 \mathrm{~cm}$; $(B, D, P)=200 \mu \mathrm{m} ;(C, F-H, J-L, N, O, R, T)=50 \mu \mathrm{m}$. Rio de Janeiro State (RJ), 2013.
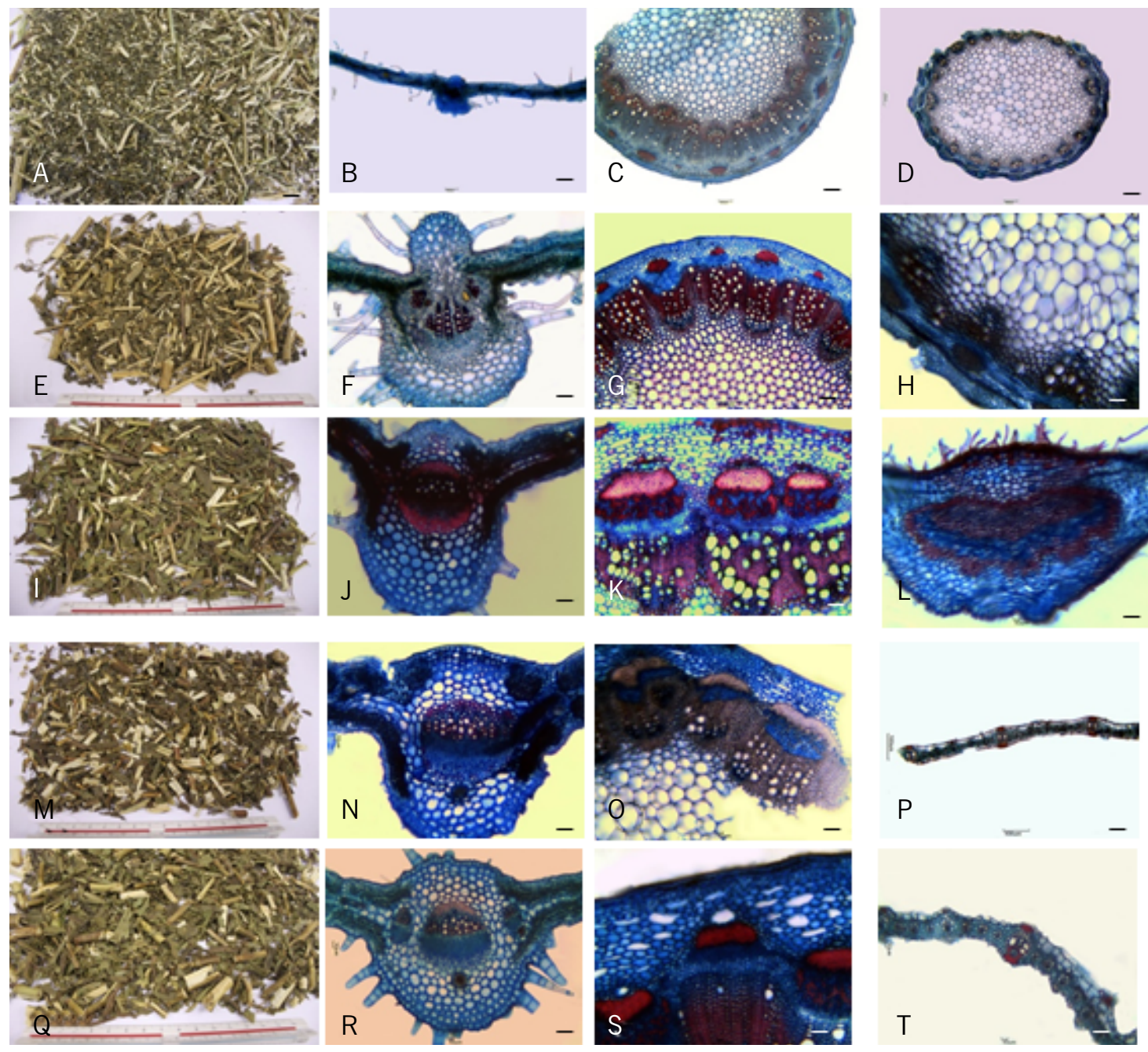

Source: Elaborated by the authors (2020).

None of the samples, even those specifically identified as Arnica montana on their labels, demonstrated any floral capitula of that species; the samples did, however, demonstrate visual similarities to Solidago chilensis regarding their leaves and aerial portions. According to Panizza and Grotta (1965), among the characteristics that can be used to identify S. chilensis are the presence (or not) of secretory canals 
associated with the vascular bundles; the tissue composition of the central nerve and lateral regions; the presence of aerenchyma in the stem; and the presence of collenchyma in the leaves. Additionally, Athayde et al. (2019) studied some species known as 'arnica", including S. chilensis, and provided morphological and chemical diagnostic markers, which could be also applied in the "arnica" quality control.

Microscopic analyses of the samples indicated serious detriment on quality due to inadequate storage of the plant material. The shredded leaves and stems (the latter should not even be present) were only able to be diagnosed after meticulous analysis and added to the heterogeneity of the material. It was possible to identify similarities between some samples, as samples II and V, and also to detect divergent material, such as sample IV - but there was not a single positive result for the primary species (Arnica montana). Similar results were obtained on studies of commercial samples of other plant remedies such as "centela", "chá verde" (green tea) and "espinheira santa" (COSTA; GUIMARÃES; VIEIRA, 2015), and "quebra pedra", "espinheira santa", "erva doce", "carqueja" and "boldo", in which no sample had been approved regarding label information and quality markers (LOPES et al. , 2019). These insights highlight the poor quality of medicinal plants sold in the country.

\section{Chemical analyses of the samples}

The microchemical analyses of different types of flavonoids showed that samples I, II, III, V, VI, VII, and VIII were similar to Solidago chilensis, notably by the presence of flavonols detected in Test 1 , and, more specifically, flavanones by Test 2 . Sample IV, however, did not contain any flavonoids at all, either by Test 1 or Test 2, indicating that its chemical constitution was divergent from the standard (what was also confirmed in the anatomical analyses).

Table 1 presents the results of the chemical tests of the samples after alcohol extraction. The materials were extracted at different $\mathrm{pHs}$ and at different temperatures to detect different types of flavonoids, followed by ultraviolet tests to detect flavanones. Table 1 also displays the qualitative microscopic results and the weights of the samples.

Table 1 - Results of the chemical and morphological analyses and the weights of the analyzed samples from Rio de Janeiro State (RJ) in 2013. Variations out of tolerance range in sample weights are indicated in bold type, according to INMETRO decree $n^{\circ} 248 / 2008$.

\begin{tabular}{ccccc}
\hline Sample & $\begin{array}{c}\text { Flavonoid Classes } \\
\text { (Test 1) }\end{array}$ & $\begin{array}{c}\text { Presence of } \\
\text { Flavonoids (Test 2) }\end{array}$ & \multicolumn{1}{c}{$\begin{array}{c}\text { Results of the } \\
\text { microscopic analyses }\end{array}$} & $\begin{array}{c}\text { Labeled weight/ } \\
\text { true weight }\end{array}$ \\
\hline I & Flavanones, Flavonols & Yes & $\begin{array}{l}\text { Not observed Solidago chilensis } \\
\text { and/or Arnica montana }\end{array}$ & $20 \mathrm{~g} / \mathbf{1 1 . 7 6 5 2 ~ g}$ \\
II & Flavanones, Flavonols & Yes & $\begin{array}{l}\text { Not observed Solidago chilensis } \\
\text { and/or Arnica montana }\end{array}$ & $15 \mathrm{~g} / 23.5700 \mathrm{~g}$ \\
III & Flavanones, Flavonols & Yes & $\begin{array}{l}\text { Not observed Solidago chilensis } \\
\text { and Arnica montana }\end{array}$ & $20 \mathrm{~g} / 19.0459 \mathrm{~g}$ \\
IV & Condensed tannins & No & $\begin{array}{l}\text { Not observed Solidago chilensis } \\
\text { and/or Arnica montana }\end{array}$ & $20 \mathrm{~g} / \mathbf{1 6 . 0 3 5 2 ~ g}$ \\
V & Flavanones, Flavonols & Yes & $\begin{array}{l}\text { Not observed Solidago chilensis } \\
\text { and/or Arnica montana }\end{array}$ & $15 \mathrm{~g} / \mathbf{1 1 . 4 0 9 4 \mathbf { g }}$ \\
VI & Flavanones, Flavonols & Yes & $\begin{array}{l}\text { Not observed Solidago chilensis } \\
\text { and/or Arnica montana }\end{array}$ & $20 \mathrm{~g} / 21.1242 \mathrm{~g}$ \\
VII & Flavanones, Flavonols & Yes & $\begin{array}{l}\text { Not observed Solidago chilensis } \\
\text { and/or Arnica montana }\end{array}$ & $20 \mathrm{~g} / \mathbf{1 4 . 5 7 7 3 ~ g}$ \\
VIII & Flavanones, Flavonols & Yes & $\begin{array}{l}\text { Not observed Solidago chilensis } \\
\text { and/or Arnica montana }\end{array}$ & $20 \mathrm{~g} / 19.0079 \mathrm{~g}$ \\
\hline
\end{tabular}

Source: Elaborated by the authors (2020). 
When it comes to the chemical analyses, seven of the eight samples would be approved according to the information contained on their labels, even though, as it has been demonstrated throughout this essay, an absolute majority of the samples would be rejected under their microscopic examination. In light of these facts, the importance of anatomical inquiry of plant materials must be emphasized to provide conclusive diagnostic evaluations; the storage conditions and handling of the plant matter must also be considered as they will greatly influence the chemical characteristics of the samples and could cause them to become less effective or even dangerous to human health.

Paes-Leme (2008) demonstrated that considerations respecting plant anatomy are of great importance to quality assurance of medicinal plants and herbal medicines and represent relevant criteria within the application of Good Manufacturing Practices. Microscopic analyses, although indispensable, can be insufficient to determine the quality of raw materials derived from plants and must be associated with chemical tests to provide conclusive results (WHO, 1998). Costa, Guimarães and Vieira (2015) correspondingly demonstrated the importance of combining morphological and microchemical studies in the analyses of commercial samples of other plant remedies.

As such, the results of our anatomical and chemical analyses of arnica products demonstrated that these techniques are complementary and capable of assuring, with good levels of reliability, the identity and quality of plant remedies through preliminary and low-cost analyses.

We hope that the present study will contribute to the establishment of specific disciplines for those elements and reduce problems caused by the lack of assurance over the quality of the raw materials offered to consumers, especially concerning the presence and percentages of contaminants.

\section{Conclusion}

The species Solidago chilensis was not listed in Annex I of the RDC $n^{\circ} 10$ of 2010, and therefore could not be commercialized in 2013, and none of the products that identified themselves as Arnica montana demonstrated any similarity to that plant. They did, however, demonstrate resemblance to the Brazilian counterpart S. chilensis. Of the samples analyzed, none possessed qualities that could guarantee their safe and efficient use, for various reasons: all of the samples demonstrated problems in their labeling, ranging from incorrect to inadequate information concerning the material used in their compositions; none of them presented all of the characteristics necessary to identify the plant indicated on the label; the absolute majority of them contained contaminants and evidence of extremely inadequate storage and handling conditions. As such, the present work demonstrated the importance of both chemical and anatomical analyses for quality control of plant raw materials.

\section{Análise da qualidade de amostras de Arnica (Arnica montana e Solidago chilensis) comercializadas no estado do Rio de Janeiro}

\section{Resumo}

Arnica montana é uma espécie nativa da Europa usada topicamente no tratamento de contusões, inflamações e dores musculares. Estudos confirmaram a atividade anti-inflamatória de extratos da planta, sendo esta atribuída à presença de lactonas. No Brasil, seu uso é substituído tradicionalmente 
pela espécie Solidago chilensis, mais adaptada ao clima tropical com similar atividade terapêutica. Sabe-se que a $S$. chilensis pode ser usada como substituta da $A$. montana por ter semelhantes ativos químicos. Foram adquiridas oito marcas diferentes de arnica no comércio do estado do Rio de Janeiro no ano de 2013. As análises realizadas foram divididas em quatro grupos: rotulagem, análise macroscópica, microscópica e microquímica. A análise de rotulagem seguiu os pontos inclusos nas RDCs $n^{\circ} 10 / 2010$ e no 26/2014. As análises morfológicas foram realizadas com auxílio de técnicas de microscopia e, posteriormente, ensaios microquímicos para a identificação dos marcadores. Os resultados indicaram ausência de amostra em total conformidade com os padrões de rotulagem; material malconservado; presença abundante de contaminantes; espécies declaradas incorretas e descrições de uso incorretas e potencialmente danosas à saúde humana.

Palavras-chave: Anatomia vegetal. Plantas medicinais. Produtos tradicionais fitoterápicos. Marcadores químicos. Marcadores de qualidade.

\section{References}

ATHAYDE, A. E. DE; RICHETTI, E.; WOLFF, J.; LUSA, M. G.; BIAVATTI, M. W. "Arnicas" from Brazil: comparative analysis among ten species. Revista Brasileira de Farmacognosia, v. 29, n. 4, p. 401 - 424, jul. 2019.

BARNES, J.; ANDERSON, L. A.; PHILLIPSON, J. D. Fitoterápicos. Artmed, Porto Alegre, RS, $3^{a}$ Ed.: 720 pp., 2012.

BRASIL. Lei 9677 de 02/07/1998. Altera dispositivos do Capítulo III do Título VIII do Código Penal, incluindo na classificação dos delitos considerados hediondos crimes contra a saúde pública, e dá outras providências. Diário Oficial da União, Brasília, 03 jul. 1998. Seção 1, p 1.

BRAZIL. ANVISA. Agência Nacional de Vigilância Sanitária. Resolução RDC n 10, de 9 de 2010. Dispõe sobre a notificação de drogas vegetais junto à Agência Nacional de Vigilância Sanitária (ANVISA) e dá outras providências. Diário Oficial da União, Brasília, 10 mar. 2010. Seção 1, p. 52.

BRASIL. ANVISA. Agência Nacional de Vigilância Sanitária. Resolução RDC n 26, de 13 de maio de 2014a. Dispõe sobre o registro de medicamentos fitoterápicos e o registro e a notificação de produtos tradicionais fitoterápicos. Diário Oficial da União, Brasília, 14 mai. 2014. Seção 1, p. 52.

BRASIL. ANVISA. Agência Nacional de Vigilância Sanitária. Instrução Normativa nº2 de 13 de maio de 2014b. Publica a "Lista de medicamentos fitoterápicos de registro simplificado" e a "Lista de produtos tradicionais fitoterápicos de registro simplificado". Diário Oficial da União, Brasília, 14 mai. 2014. n. 90, Seção 1, p. 58.

BRASIL. ANVISA. Agência Nacional de Vigilância Sanitária. Farmacopeia Brasileira, Brasília; volume 2: 6a Ed. 2019.

BRASIL. Ministério da Saúde. Portaria GM/MS n².960, de 9 de dezembro de 2008. Aprova 0 Programa Nacional de Plantas Medicinais e Fitoterápicos e cria o Comitê Nacional de Plantas Medicinais e Fitoterápicos [Internet]. [cited 201616 mar] Available in: http://bvsms.saude.gov.br/ bvs/saudelegis/gm/2008/pri2960_09_12_2008.html. 2008 
BRASIL. Ministério da Saúde. Relação de Plantas Medicinais de Interesse ao SUS [Internet]. [cited $201616 \mathrm{mar}$ ] Available in: http://bvsms.saude.gov.br/bvs/sus/pdf/marco/ms_relacao_plantas_ medicinais_sus_0603.pdf. 2009.

BRASIL. MDIC. Portaria Inmetro n² 248 de 17 de julho de 2008. Regulamento técnico metrológico a que se refere a portaria INMETRO $n^{0} 248$ de 17 de julho de 2008.

COSTA, R. P. C.; GUIMARÃES, A. L. A.; VIEIRA, A. C. M. Avaliação da Qualidade de Amostras de Plantas Medicinais Comercializadas no Brasil. Revista de Ciências Farmacêuticas Básica e Aplicada, v. 35, n. 3, p. 425-433, 2015.

GASTALDI, B.; CATALÁN, C. A. N.; SILVA-SOFRÁS, F. M.; GONZÁLEZ, S. B. Solidago chilensis Meyen (Asteraceae), a medicinal plant from South America. A comprehensive review: ethnomedicinal uses, phytochemistry and bioactivity. Boletín Latinoamericano y del Caribe de Plantas Medicinales y Aromáticas, v. 17, n. 1, p. 17-29, 2018.

HALL, I. H. Anti-inflammatory activity of sesquiterpene lactones and related compounds. Journal of Pharmaceutical Sciences, v. 68, n. 5, p. 537-542, 1979.

KELLY, A. M.; OLIVEIRA, T. B. DE; VALVERDE, S. S. Determination of the metabolic profile of Solidago canadensis using UFLC-PDA-ESI-TOF. Rodriguésia, v. 71, p. 01062019, 2020.

KRAUS. J. E.; ARDUIN, M. Manual básico de métodos em morfologia vegetal. EDUR, Seropédica, RJ: 198 pp., 1997.

LOPES, A. C.; OLIVEIRA, V. J. S.; SILVA, L. L. S. C.; MASCARENHAS, L. S.; BRITO, N. M. CONTROLE DE QUALIDADE DE ERVAS MEDICINAIS COMERCIALIZADAS EM SANTO ANTÔNIO DE JESUS-BA. Journal of Biology, v. 15, n. 3, p. 15, 2019.

LORENZI, H.; MATOS, F. J. A. Plantas Medicinais do Brasil. Instituto Plantarum de Estudos da Flora Ltda, Nova Odessa, SP, $2^{\text {a }}$ Ed: 576 pp., 2008.

LYSS, G.; SCHMIDT, T. J.; MERFORT, I.; PAHL, H. L. Helenalin, an anti-inflammatory sesquiterpene lactone from Arnica, selectively inhibits transcription factor NF-kappa B. Bollettino chimico farmaceutico, v. 378, n. 9, p. 951-961, 1997.

MATOS, F. J. A. Introdução à Fitoquímica Experimental. Ed. UFC, Fortaleza, CE; 2a Ed: 141 pp., 1997.

NEWALL, C. A.; ANDERSON, L. A.; PHILIPSON, J. D. Plantas medicinais: guia para profissional de saúde. São Paulo. Premier: 40-41, 2002

PAES-LEME, A. C. V. A Importância da Microscopia no Controle de Qualidade de Drogas de Origem Vegetal, 2008. 40 f. [Monography (Especialização em Tecnologia Industrial Farmacêutica), Faculdade de Farmácia, Universidade Federal do Rio de Janeiro, Rio de Janeiro, RJ] 
PANIZZA, S; GROTTA, A. S. Contribuição ao estudo morfológico e anatômico de Solidago chilensis DC. Compositae. Revista da Faculdade de Farmácia e Bioquímica da Universidade de São Paulo, v. 3, p. 27-50, 1965.

THE PLANT LIST. Version 1.1. Solidago microg/ossa DC. [Internet]. [cited 201616 mar] Available in: http://www.theplantlist.org/tpl1.1/record/gcc-116108. 2016.

WORLD HEALTH ORGANIZATION. Quality control methods for medicinal plant materials. Geneva, 1998. 123p.

WOERDENBAG, H.J.; MERFORT, I.; PASSREITER, C.M.; SCHMIDT, T.J.; WILLUHN, G.; VAN UDEN, W.; PRAS, N.; KAMPINGA, H.H.; KONINGS, A. W. Cytotoxicity of flavonoids and sesquiterpene lactones from Arnica species against the GLC4 and the COLO 320 cell lines. Planta Medica, v. 60, n. 5, p. 434-437, 1994.

Received: July 28, 2020

Accepted: November 5, 2020 